\title{
Anthós
}

\section{The Venus Victorieuse and Renoir's treatment of the Female Nude}

Tess Yinger

Portland State University

Follow this and additional works at: https://pdxscholar.library.pdx.edu/anthos

Part of the Theory and Criticism Commons Let us know how access to this document benefits you.

\section{Recommended Citation}

Yinger, Tess (2010) "The Venus Victorieuse and Renoir's treatment of the Female Nude," Anthós: Vol. 2: Iss. 1, Article 6.

https://doi.org/10.15760/anthos.2010.49

This open access Article is distributed under the terms of the Creative Commons Attribution-NonCommercialShareAlike 4.0 International License (CC BY-NC-SA 4.0). All documents in PDXScholar should meet accessibility standards. If we can make this document more accessible to you, contact our team. 
The Venus Victorieuse and Renoir's treatment of the Female Nude

Thesis: Pierre-Auguste Renoir's sculpture Venus Victorieuse is a mythic image of the 'ideal' woman that was influenced by The Judgment of Paris, the Aphrodite of Knidos, and the imagery of Eve in the Garden of Eden. This work is fundamental to realizing Renoir's overall treatment of the female nude, which is fully epitomized by this formal sculpture.

Pierre-Auguste Renoir was an Impressionist artist who dedicated the last three decades of his life primarily to the depiction of the female nude. ${ }^{1}$ His representation of the nude, both in painting and sculpture, was monumental and idealized, and he often created images of women that were mythic and evocative of the notion that woman belongs to the 'natural sphere. ${ }^{2}$ Renoir's sculpture, the Venus Victorieuse is an idealized and indeed mythic image that epitomizes the idea of woman as a seducer, animalistic by nature and inherently amoral. The first part of this essay will discuss the ways in which the Venus Victorieuse was influenced by two earlier works, The Judgment of Paris by Marcantonio Raimondi and Praxiteles' Aphrodite of Knidos, and also how this image of Venus evokes the allegory of Eve and the notion of her 'original sin'. Comparing the Venus with these two earlier works will address these influences and how they have informed the meaning behind Renoir's sculptural interpretation of the mythic symbol of Venus. The second part of this essay will explore the ways in which Renoir has utilized the sculptural form to convey

\footnotetext{
${ }^{1}$ Kenneth Clark, Feminine Beauty (New York: Rizzoli International Publications, 1980) 163.

2 Tamar Garb, "Painterly Plenitude: Pierre-Auguste Renoir's Fantasy of the Feminine” in Bodies of Modernity: Figure and Flesh in Fin-de-Siècle France (London: Thames and Hudson, 1998) 150.
} 
his ideas concerning the objectification of woman and the implications of her as inherently closer to nature, predisposed to sin and seduction.

Looking at Renoir's sculpture of the Venus Victorieuse (Figure 1)

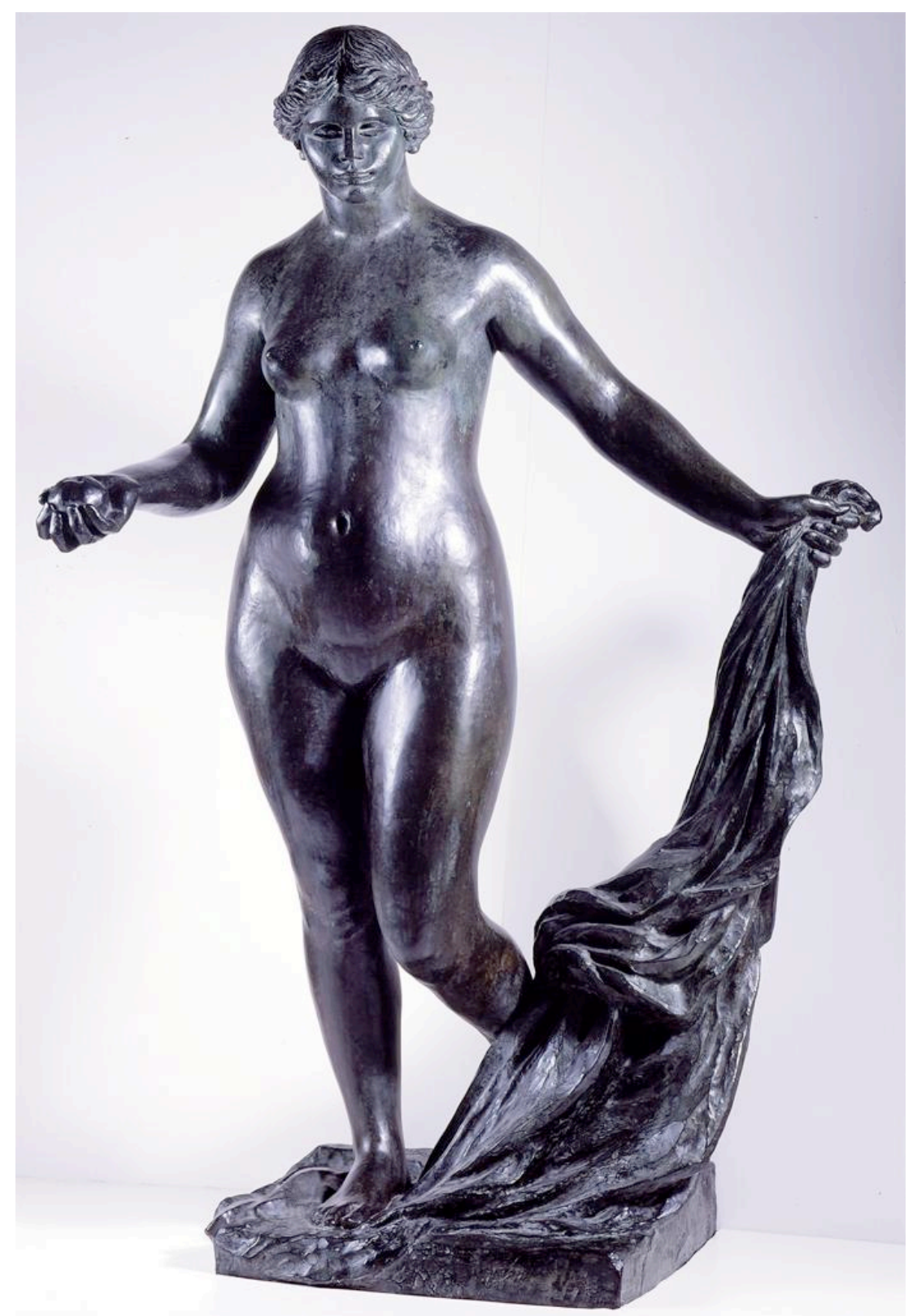

Figure 1. Pierre-Auguste Renoir, Venus Victorieuse, 1916. Bronze sculpture, 180 x $110 \mathrm{~cm}$.

and comparing this representation of the goddess with Marcantonio Raimondi's image (Figure 2), 


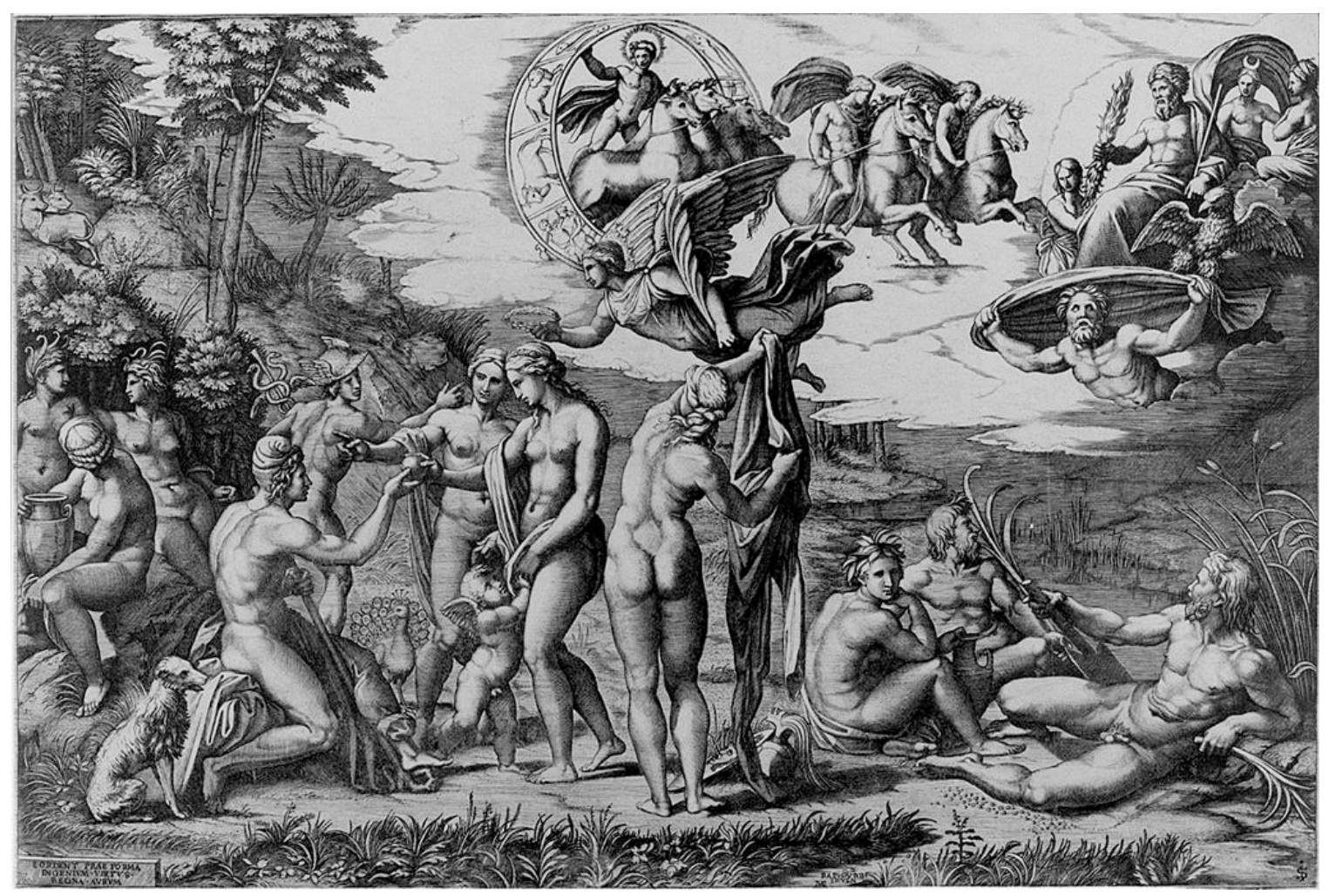

Figure 2. Marcantonio Raimondi, The Judgment of Paris, ca. 1516. Engraving, 298 x 442 mm. London.

we notice several ways in which Renoir has used Raimondi's engraving to influence his sculpture. It also becomes apparent how Renoir has also altered and elaborated on the image of the victorious Venus to imbue the figure with his interpretation of feminine ideals. First, notice the position of Venus in The Judgment of Paris; the image of Venus in this piece is leaning in to take the apple out of Paris' hand while holding onto her garment with her other hand. The pose of Venus suggests slight movement toward Paris, with her posture weighing into the front foot conveying an eagerness to claim the prize. ${ }^{3}$ The other two goddesses who have just lost the competition are close by, flanking Venus. Her left hand is placed modestly over her genitalia, and her hair is in a braid that crowns her head and falls

\footnotetext{
${ }^{3}$ Hubert Damisch, The Judgment of Paris (Chicago: University of Chicago Press, 1996), 92.
} 
down her back. Renoir's Venus is similar to Raimondi's engraved Venus in several ways. First, notice how similarly the two Venuses stand. The goddess is grasping the apple in victory, her left hand also clutches a garment of sorts, and her hair is coiffed in a beautiful crown that is significantly reminiscent of Raimondi. The idealized body shape of Renoir's Venus is also mirrored in Raimondi's work, with all her body parts represented in a highly romanticized fashion; serenely smooth skin, vacant face, voluptuous hips and belly. Both women have overwhelmingly similar body shapes and proportions. In both of these pieces, the faces of the women are also clearly idealized in the sense that they are both somewhat blank, nearly expressionless, conveying an appearance of distance and aloofness.

While the faces and bodies of these two subjects are similar, their differing contexts and body language inform us of Renoir's intention behind his piece. First, let us address the posture of the women. The Venus Victorieuse is positioned in such a way that the shift of her weight is placed into her back foot. This more traditional contrapposto pose is more erect and reminiscent of the centuries earlier Aphrodite of Knidos (Figure 3). 


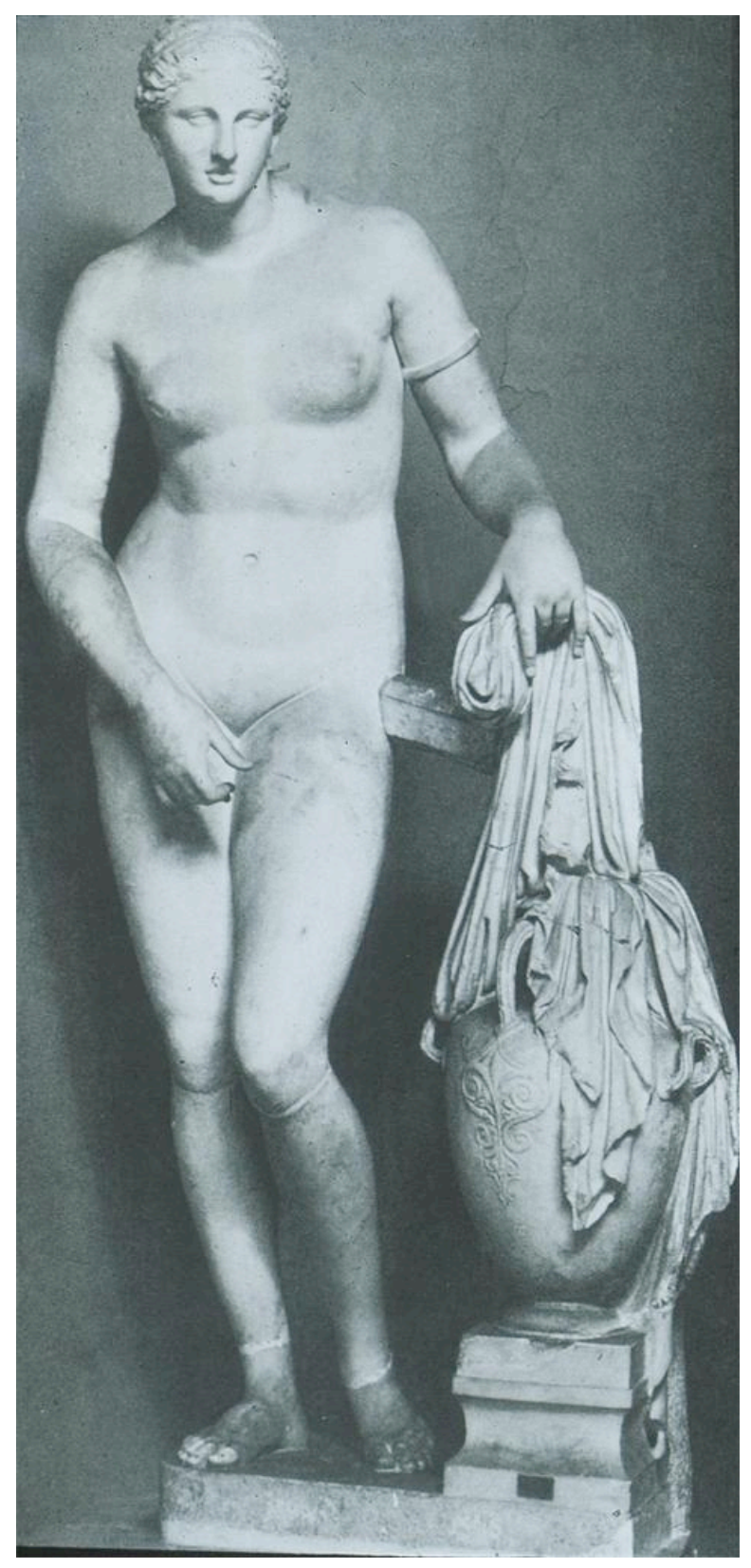

Figure 3. Praxiteles, Aphrodite of Knidos, ca. 350-30 BCE. Marble.

Praxiteles' Aphrodite of Knidos is a sculpture (unlike Raimondi's engraving), which provides further insight into the three-dimensional qualities of Renoir's Venus Victorieuse. Like the Venus, the Knidian Aphrodite is positioned with her weight placed on her back foot, and her left hand is clutching a garment that is being set aside. With the Knidian Aphrodite, we see a robe being put down as the goddess prepares to take a bath. Her posture is 
contrapposto, and her right hand is placed modestly over her genitals. If we compare this image with that of the Venus Victorieuse we notice that the Venus is also holding her garment as if to discard it beside her. The movement of the garment also indicates a swiftness with which it is being discarded. While the garment that the Aphrodite holds is being clutched modestly, set aside gently before her bath, the garment that the Venus Victorieuse is clutching is being tossed aside assertively as if the Venus is openly rejecting the clothing, and affirming the comfort of the 'natural' state of her nudity.

In her book The Female Nude: Art, Obscenity, and Sexuality, Lynda Nead brilliantly argues that the "physical dimensions of the free-standing statue might be seen to enhance the potential for sexual arousal."4 The formal elements of sculpture lend themselves to further create an idea of the fantastical woman, one that is gazed upon, idealized, and fantasized about, but unattainable. Renoir's image of the Venus Victorieuse epitomizes this. Instead of a painting of the goddess of sexuality, Renoir sculpted her, creating the image of Venus as the literal work of art, a sculptural object, rather than the subject of a painting. This assertion is important in realizing Renoir's allusion to woman as an object of nature, something to be gazed upon and idolized as such.

Upon addressing the formal elements of these three pieces, we are now able to use the comparisons to further interpret the Venus Victorieuse and her significance as an image of Renior's ideal woman, existing within the natural sphere. First, let us look at the apple in the hand of the Venus Victorieuse. Arm outreached, slightly bent, the apple is in a position so that it seems as though it is being offered by rather than given to the Venus. In Tamar Garb's article "Renoir and the Natural Woman,” Garb asserts that Renoir's depictions of

\footnotetext{
${ }^{4}$ Lynda Nead, The Female Nude: Art, Obscenity, and Sexuality (London: Routledge Press, 1992$) 87$.
} 
women were used to “invoke [a woman's] economic, intellectual, and spiritual dependence on men in the name of salvation of women." ${ }^{\prime 5}$ Humanity's blame for eternal damnation rests solely in the hands of one biblical woman, Eve, whose inherent immorality led her to commit the 'original sin.' Taking Garb's assertion one step further, it can be argued that Renoir's Venus Victorieuse epitomizes this idea. With her apple in hand, the Venus is also clearly an allegory for Eve, sinful by nature, and effortlessly (even naturally) seductive. Renoir, like many of his contemporaries, also believed that women were dangerous because of their seductive power, ${ }^{6}$ which further defines the apple in the hand of the Venus Victorieuse as an allegory for Eve and her 'seduction' of Adam. The posture and body position of the Venus is also indicative of seduction. Unlike the modest position of the Aphrodite of Knidos and the Venus represented in Raimondi's etching, the Venus Victorieuse is standing erect, arms and hands positioned so that her body is open to the viewer, inviting the viewer to gaze at her. If we take a closer look at the significance of the garment placed in the left hand, it becomes clear that the Venus Victorieuse is indeed an allegory for the mythic 'ideal woman' as described by Garb. ${ }^{7}$ While past Renoir works have shown models holding a garment to conceal their genitalia, the garment that the Venus Victorieuse holds is being thrown aside rather assertively. This lack of concealment and shame by either the garment or her hand implies her sexual knowledge, comfort in nudity, and hence her sinful and animalistic nature. In Raimondi's Judgment of Paris, the three competing goddesses are shown together, standing closely to Paris. In Renoir's piece, he

\footnotetext{
5 Tamar Garb, “Renoir and the Natural Woman," Oxford Art Journal 8:2 (1985): 4.

${ }^{6}$ Ibid., 5.

7 Tamar Garb, The Body in Time: Figures of Femininity in Late Nineteenth-Century France (Lawrence: The University of Kansas Press, 2008) 56.
} 
has chosen to depict not only the winning goddess, but the winning goddess standing alone, without the other two women. From this subtraction we can infer that because Venus was the goddess of beauty and fertility, she intrigued Renoir above the other two goddesses, Athena and Hera, goddesses of war and marriage respectively.

In her book The Nude in French Art and Culture, Heather Dawkins asserts that the "adoration of women implied by the [Impressionist] genre was replaced by studied objectivity, disdain, or misogyny."8 Pierre-Auguste Renoir's sculpture of Venus Victorieuse is a strong embodiment of this argument in several distinct ways. With her expressionless face and erect body position, the Venus Victorieuse is symbolic of the mythically ideal woman. Renoir created this image of the Venus with undercurrents of the work of both Praxiteles and Marcantonio Raimondi, with emphasis on the context of these ideal portrayals of women in the past. Using the allegory of Eve's original sin and the seduction of Adam in combination with the object of the naked female form, Renoir implies an inherent immorality and closeness to nature that had been assigned as a characteristic of women. Using this sculpture as a vessel, Pierre-Auguste Renoir has created an image of woman as inherently seductive and amoral, as was common with the representation of most nude women at that time.

\footnotetext{
${ }^{8}$ Heather Dawkins, The Nude in French Art and Culture 1870-1910 (Cambridge: Cambridge University Press, 2002) 85 .
} 
Bibliography

Clark, Kenneth. Feminine Beauty (New York: Rizzoli International Publications, 1980).

Damisch, Hubert. The Judgment of Paris (Chicago: The University of Chicago Press, 1996).

Dawkins, Heather. The Nude in French Art and Culture, 1870-1910 (Cambridge: Cambridge University Press, 2002).

Garb, Tamar. "Painterly Plenitude: Pierre-Auguste Renoir's Fantasy of the Feminine." Chapter 5 in Bodies of Modernity: Figure and Flesh in Fin-de-Siècle France. London: Thames and Hudson, 1998.

Garb, Tamar. "Renoir and the Natural Woman." Oxford Art Journal 8, no. 2 (1985): 3-15.

Nead, Lynda. The Female Nude: Art, Obscenity and Sexuality (New York: Routledge, 1992). 